\title{
Investigation on the Reproducibility of the Psychological Perspiration Test in Healthy Volunteers
}

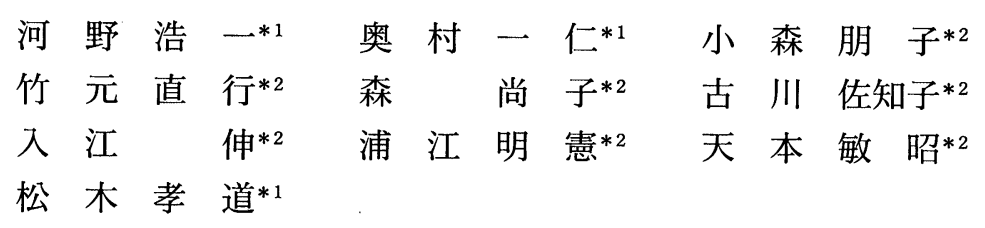

The perspiration seen on the surface of palms or soles, which is caused by the stimulation of autonomic nervous system due to psychological stress, is called "psychological perspiration (PP)". Recently, it became possible to measure the PP quantitatively and continuously by a newly developed apparatus, Kenz-Perspiro OSS100 (Suzuken Co., Ltd.) ${ }^{1}$.

We think that the PP test can be useful for evaluating biological responses in the phase I studies for drugs which affect on the system related to the PP from central to peripheral. Therefore, we studied the reproducibility of the PP test by taking into account the conditions of phase I studies.

Methods : Twelve healthy male volunteers from 21 to 24 years old (mean: 22.6 years old) were enrolled in the study, and randomly allocated into two groups ( $A$ or $B$ ) of six each. In group $A$, the PP test was performed five times in 24 hours at intervals of $1,1,6$ and 16 hours. In group $B$, total of three tests were conducted at 8 and 16 hours intervals.

At each test, the subjects received four

\footnotetext{
*1 バイエル薬品侏研究・開発/臨床薬理

干 532 大阪市淀川区宮原 3-5-36

*2 相生会臨床薬理センター
}

kinds of stimuli which induces PP, such as mental arithmetic, hand gripping, sole rubbing and sudden inspiration, in a randomized order.

Throughout each test, perspiration was measured at the right hand thenar of the subjects in supine position. The increased amount and peak level of the perspiration after loading each stimulus were calculated as indices of the perspiration response.

Results : In group $A$, in which the second test was performed after a short interval (1 $\mathrm{hr}$ ), both the amount and peak level of perspiration at the second test decreased obviously compared to the values at the first test in all four stimuli. On the other hand, in group $B$, the PP response did not decrease in the second test which was conducted after a longer interval compared to group $A$ (8-hours interval). However, the mean values of perspiration amount and peak values at the first test in group $A$ were distinctly higher than group $B$.

When comparing among the four stimuli in group A, the largest decrease of the PP response was observed with mental arithmetic.

In group A, decreased PP response at the second test did not recover thereafter and were stable until the fifth test, whereas in 
group $B$, the PP response was invariable from the first to the third (last) test (Fig.).

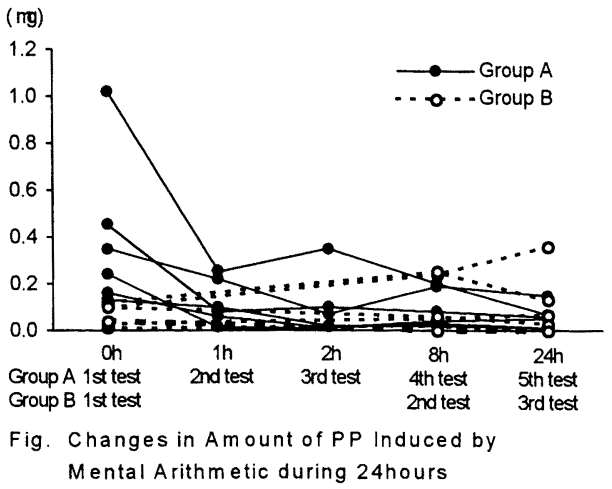

Discussion : The reason for the lowered PP response which was observed at the second test in group $A$ was considered to be related to the adaptational phenomena ${ }^{2), 3)}$. However, it can not be judged whether this lowered response is due to the shorter interval between the tests or if there is a specific reason in the subjects who showed higher response at the first test, because the PP response at the first test in group $A$ was obviously higher compared to group $B$.
The largest decrease of PP response was seen with mental arithmetic, which showed the highest PP response at the first test among the four stimuli. This fact may also suggest that the high response affects on the decrease in the next response.

Nevertheless, the results after the second test showed good reproducibility in both groups. Consequently, it is considered that the PP test can be used as a new psychometric examination in phase I studies and would be a good measure for evaluating the drug effects by using the values from the second test as a baseline.

\section{References}

1）大橋俊夫：新しいタイプの局所発汗量連続 記録装置の開発とその医学への忍用. 発汗 学, $1: 3-8$ (1994).

2）小林正義，牛山喜久，大橋俊夫：精神性発 汗とその誘発刺激の検討. 発汗学, 1 : 12-14 (1994).

3）岩橋成寿：（2）ストレス負荷法への応用. 大橋俊夫, 宇尾野公義 (編)：精神性発汗 現象一測定法と臨床的応用一，第1版，スズ ケン医療機器事業部, 名古屋, pp131-142 (1993). 